\title{
Generational Spending Habits
}

\section{Debra Wetcher-Hendricks and Mitchell Hendricks ${ }^{1}$}

The expectation of familiarity with technologies embedded in millennial lifestyle creates a sort of cultural lag, with older generations struggling to understand and use these technologies. However, older generations' failure to accept new technologies, at least to some degree, would lead to social stagnation. From a populist standpoint, concerns of both generations deserve attention. Hypotheses contend that those in younger generations feel greater strain when using electronic payments than when using currency and that those in older generations feel greater strain when using currency than when using electronic payments. Data gathered from individuals of various ages and in various socio-economic statuses provided moderate, but not overwhelming, support for this contention. However, other, unanticipated, patterns emerge. [Article copies available for a fee from The Transformative Studies Institute. E-mail address:_journal@transformativestudies.org Website: http://www.transformativestudies.org (C2022 by The Transformative Studies Institute. All rights reserved.]

KEYWORDS: Millennial, Generation X, Cultural Lag, Consumerism.

\section{LITERATURE REVIEW}

The well-known musical Cabaret contains a song with the lyric, "Money makes the world go round" (Ebb 1966). Few could argue. In today's world, money is a cultural universal (Mauer 16), meaning that it exists as

\footnotetext{
${ }^{1}$ Debra Wetcher-Hendricks, Ph.D., holds the rand of full professor of Sociology and Anthropology Department at Moravian College. She has authored Analyzing Quantitative Data: An Introduction for Social Researchers and presented her statistical analyses and models in academic journals and at conferences.

Mitchell Hendricks is an undergraduate double major in Music and Political Science with a concentration in Legal Studies. His interests in public policy and entertainment law drive his academic agenda. He proudly participates on the Monmouth University Debate team, nationally ranked, in 2020, as \#1 in the Cross Examination Debate Association's Novice Division.
} 